\title{
Occurrence of Vestalenula (Darwinuloidea, Ostracoda) in the Neogene of Italy, Crete and Serbia, with the description of three new species
}

\author{
SILVIA LIGIOS ${ }^{1, *}$, KLAUS MINATI $^{2}$, ELSA GLIOZZI $^{1,3} \&$ NADEZDA KRSTIC $^{4}$ \\ ${ }^{1}$ Dipartimento di Scienze Geologiche, Università degli Studi Roma Tre Largo S. Leonardo Murialdo, 1 - 00146 Rome, Italy \\ ${ }^{2}$ Institute for Earth Sciences, University of Graz Heinrichstrasse 26, 8010 Graz, Austria \\ ${ }^{3}$ IGAG, CNR Rome, Italy \\ ${ }^{4}$ Nature History Muzeum, Njegoseva 51, 11000 Belgrade, Serbia \\ ${ }^{*}$ Corresponding author (e-mail: ligios@uniroma3.it)
}

\begin{abstract}
The morphology of fossil remains of Vestalenula (Darwinuloidea, Ostracoda) from Crete (Greece), Serbia and Italy were analysed using morphometric valve variability analysis. Three new species were distinguished and described, Vestalenula angulata $\mathrm{n}$. sp., Vestalenula longissima $\mathrm{n}$. sp. and Vestalenula pliocenica $\mathrm{n}$. sp., and represent the first record of this genus in the Neogene of Italy and Serbia. Vestalenula angulata $\mathrm{n}$. sp. was recorded from the early Messinian of Tuscany, Italy (Baccinello and Velona Basins), Vestalenula longissima $\mathrm{n}$. sp. was collected in the Upper Pliocene (Gelasian) sediment core drilled in the Sabina area (Latium, Italy), and Vestalenula pliocenica $\mathrm{n}$. sp. was collected from the Early Tortonian of Vrysses (Rethymnon Basin, Crete), from the lower Messinian deposits of the Velona Basin (Tuscany, Italy), in the Late Pliocene of the Paludinian Beds (Middle Danube Plain) and Mazgoš deposits (Serbia), and in the Upper Pliocene deposits of the Sabina area (Latium, Italy). Despite the freshwater character of most living species of Vestalenula, the fossil species here analysed were found associated with halotolerant forms, showing they could also withstand oligohaline conditions. J. Micropalaeontol. 28(2): 99-115, November 2009 .
\end{abstract}

KEYWORDS: Ostracoda, Vestalenula, Neogene, comparative morphology, taxonomy

\section{INTRODUCTION}

The genus Vestalenula (Ostracoda, Darwinuloidea) was established by Rossetti \& Martens (1998) on the basis of the presence of a postero-ventral keel on the right valve and an internal small antero-ventral tooth on the left valve. At present the genus is represented by fifteen living species and four forms left in open nomenclature (Rossetti \& Martens, 1998, 1999; Martens \& Rossetti, 2002; Pinto et al., 2003; Smith et al., 2006; Artheau, 2007) grouped within two lineages: the danielopoli-group (including four species) in which the external keel and the internal tooth are elongate, and the boteai-group where, on the contrary, the tooth and the keel are short (Table 1).

While the genus seems to be widespread from Cuba, Brazil, Africa, Sri Lanka, New Caledonia, Australia, Japan, central Europe, Solomon Island and Israel, mainly with a southern distribution, each living species seems to be geographically confined to the area from which it was originally described (Artheau, 2007).

Few fossil Vestalenula have been recorded and these mainly from Neogene and Quaternary deposits of Europe (Portugal, Switzerland, Austria, Germany, Slovakia, Croatia, Serbia, Greece) (Straub, 1952; Lutz, 1965; Sokač, 1979; Mostafawi, 1988, 1989, 1990, 1994; Krstić, 1995, 2006; Janz, 1997; Martens et al., 1997; Rossetti \& Martens, 1998; Witt, 1998, 2000; Ghetti et al., 2002; Pipik \& Bodergat, 2003; Gross, 2004; Cabral et al., 2005; Ligios et al., 2008; Minati et al., 2008) and western Asia (Turkey, Iran and Socotra island) (Freels, 1980; Janz et al., 2001; Mazzini \& Sardella, 2004) (Table 2). To date, only Vestalenula cylindrica (Straub, 1952), V. flandrini (Carbonnel, 1985), V. danielopoli (Martens et al., 1977) and Vestalenula sp. Mazzini \& Sardella, 2004 have been recovered as fossil material (Table 2).
In the present paper the genus Vestalenula is recorded for the first time in Italy and Serbia and the recovered valves were investigated from a detailed taxonomical perspective. In order to better evaluate the slight interspecific valve shape variations typical of the known Vestalenula species, the present taxonomical analysis is supported by a geometric morphometric analysis, following Baltanás et al. (2003), Brauneis et al. (2006a, b), Iepure et al. (2007), Minati et al. (2008) and Gross et al. (2008).

\section{STUDIED LOCALITIES}

The analysed Vestalenula specimens come from different Italian, Serbian and Cretan localities (Fig. 1), spanning the Early Tortonian to Late Pliocene (Gelasian).

The Early Tortonian-Early Messinian composite section of Vrysses is located in the Rethymnon Basin, about $22 \mathrm{~km}$ southeast of Khania (northwestern coast of Crete). The lower portion comprises alternating silty clays and lignites deposited in freshwater-brackish environments; the upper part is represented by shallow-marine marly limestones and clays (Meulenkamp, 1979; Mostafawi, 1989), which span the Neogloboquadrina acostaensis Biozone to the Globorotalia miotumida Biozone. The Vestalenula specimens analysed in this paper were collected from the lower brackish portion (sample KR 10) and were associated with Candona (Neglecandona) angulata Müller, 1900, Cyprideis and Characeae gyrogonites.

The Italian specimens of Vestalenula were collected from the lower Messinian deposits of Baccinello-Cinigiano and Velona basins (Tuscany, central Italy) and from the Upper Pliocene (Gelasian) deposits of the Sabina area (Latium, central Italy).

The Baccinello-Cinigiano and Velona basins are two extensional tectonic depressions which, during the Late Miocene, were filled by continental deposits linked to lacustrine, 


\begin{tabular}{|c|c|c|}
\hline Recent Vestalenula species & Geographical distribution & References \\
\hline \multicolumn{3}{|l|}{ danielopoli group } \\
\hline $\begin{array}{l}\text { Vestalenula cornelia Smith, Kamiya \& Horne, } \\
2006\end{array}$ & $\begin{array}{l}\text { Freshwater springs on Honshu,Yakushima, } \\
\text { Anami-Oshima and Ogasawara Islands, Japan }\end{array}$ & Smith et al. (2006) \\
\hline Vestalenula matildae Martens \& Rossetti, 2002 & Interstitial, Ashburton River valley, Australia & Martens \& Rossetti (2002) \\
\hline Vestalenula carveli Artheau, 2007 & Subterranean, Russillon, S France & Artheau (2007); Danielopol et al. (2009) \\
\hline Vestalenula sp. A Danielopol, 1980 & $\begin{array}{l}\text { Phreatic lake, Cueva del Aqua, Canaguey, } \\
\text { Cuba }\end{array}$ & Danielopol (1980) \\
\hline Vestalenula sp. B Danielopol, 1980 & $\begin{array}{l}\text { Oued el Lebga and Oued Delma, } \\
\text { northwestern Tunisia }\end{array}$ & Danielopol (1980) \\
\hline \multicolumn{3}{|l|}{ boteai group } \\
\hline Vestalenula boteai (Danielopol, 1970) & Interstitial, Mraconia river, Romania & Danielopol (1970) \\
\hline $\begin{array}{l}\text { Vestalenula botocuda Pinto, Rocha \& } \\
\text { Martens, } 2003\end{array}$ & Mud at Mulungu, Sao Paulo State, Brazil & Pinto et al. (2003) \\
\hline Vestalenula cuneata (Klie, 1939) & Spring at Kikuyu, Kenya & Klie (1939) \\
\hline Vestalenula daps (Harding, 1962) & Lake Te-Nggano, Solomon Islands & Harding (1962) \\
\hline Vestalenula flexuosa Rossetti \& Martens, 1999 & Several pools, Namibia & Rossetti \& Martens (1999) \\
\hline Vestalenula incospicua $(\mathrm{Klie}, 1935)$ & Bandama River, Ivory Coast & Klie (1935) \\
\hline $\begin{array}{l}\text { Vestalenula irajai Pinto, Rocha \& Martens, } \\
2003\end{array}$ & $\begin{array}{l}\text { Small patches of water and among leaves and } \\
\text { mosses, Sao Paulo State, Brazil }\end{array}$ & Pinto et al. (2003) \\
\hline Vestalenula lundi (Neale \& Victor, 1978) & Sandy riverbank, Sri Lanka & Neale \& Victor (1978) \\
\hline Vestalenula marlieri (Kiss, 1959) & $\begin{array}{l}\text { Luhanga stream, northern extremity of Lake } \\
\text { Tanganika, Democratic Republic of Congo }\end{array}$ & Kiss (1959) \\
\hline $\begin{array}{l}\text { Vestalenula marmonieri Rossetti \& Martens, } \\
1999\end{array}$ & $\begin{array}{l}\text { Tributary of Diahot River, New Caledonia } \\
\text { Island; Yonderup Lake, Australia; Eil Eil } \\
\text { Spring, Australia }\end{array}$ & $\begin{array}{l}\text { Davis \& Christidis (1997); Rossetti \& Martens } \\
\text { (1999); Mary \& Marmonier (2000); Martens } \\
\text { \& Rossetti (2002) }\end{array}$ \\
\hline $\begin{array}{l}\text { Vestalenula molopoensis (Martens \& Rossetti, } \\
\text { 1997) }\end{array}$ & $\begin{array}{l}\text { Riverine pools, Marico River, Molopo, } \\
\text { Republic of South Africa }\end{array}$ & Martens \& Rossetti (1997) \\
\hline Vestalenula pagliolii (Pinto \& Kotzian, 1961) & $\begin{array}{l}\text { Riverine pools, Porto Alegre, Rio Grande do } \\
\text { Sul, Brazil }\end{array}$ & Pinto \& Kotzian (1961) \\
\hline Vestalenula sp. C Rossetti \& Martens, 1999 & Spring, near the Dead Sea, Israel & Rossetti \& Martens (1999) \\
\hline Vestalenula sp. D Rossetti \& Martens, 1999 & Lake Sibaya, Republic of South Africa & Rossetti \& Martens (1999) \\
\hline
\end{tabular}

Table 1. List of the extant species of the genus Vestalenula and associated type-localities.

fluvio-lacustrine and fluvial environments. The BaccinelloCinigiano section of Ribaldella $\left(42^{\circ} 50^{\prime} 45^{\prime \prime} \mathrm{N}, 11^{\circ} 21^{\prime} 41^{\prime \prime} \mathrm{E}\right)$ is a $16 \mathrm{~m}$ thick succession of massive lacustrine silts, with a $4 \mathrm{~m}$ thick intercalation of a cemented matrix-supported conglomerate of fluvial origin (Ligios et al., 2008). The Vestalenula specimens come from samples BA 61, BA 74, BA 75 and BA 80. The Velona specimens come from two nearby sections at Orcia

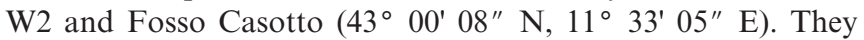
comprise a fining-upward succession of conglomerates, sands and clays, with lignite intercalations, deposited in a shallowlacustrine environment (Rook \& Ghetti, 1997; Ghetti et al., 2002). Vestalenula valves occurred in samples OW2/1, VE 2, VE 36 and VE 59.

The investigated Latium (central Italy) deposits are located in the Sabina area, northeast of Rome. The Vestalenula specimens come from sample PBS 1 collected at the Colle Cigliano (Marcellina) section $\left(42^{\circ} 00^{\prime} 21^{\prime \prime} \mathrm{N}, 12^{\circ} 47^{\prime} 43^{\prime \prime} \mathrm{E}\right)$, from sample 10 of the borehole ARI1LGT19 (42 $\left.11^{\prime} 00^{\prime \prime} \mathrm{N}, 12^{\circ} 44^{\prime} 54^{\prime \prime} \mathrm{E}\right)$ and from sample 5 of the borehole ERI1LGT18 (42 $11^{\circ}$ ' $04^{\prime \prime} \mathrm{N}$, $12^{\circ} 44^{\prime} 51^{\prime \prime}$ E) near Colle S. Lorenzo (Fara in Sabina). Both sedimentary successions comprise alternating sands, silty sands and clays deposited in continental to marginal-marine subaqueous environments (Fubelli et al., 2006).

Serbian Vestalenula specimens come from four localities, the Danube island of Opatovačka Ada, at the Serbian-Croatian boundary, Čelarevo (near Gložanjska Čarda on the Danube, Ugrinovci near Belgrade) and Mazgoš at the Serbian-Bulgarian boundary.

On Opatovačka Ada island, borehole DP-2 was drilled into the Middle and Upper Paludinian Beds (Krstić, 2006). The $150 \mathrm{~m}$ long sediment core was made of sandy gravel sediments intercalated with silts, grey marly silts and clayey silts. The sample at $72 \mathrm{~m}$ (Middle Paludinian Beds), bearing one Vestalenula valve, was collected from grey silts rich in carbonate concretions.

At Čelarevo, the G-3 borehole was drilled into the Middle and Lower Paludinian Beds. The succession is made up of silty clays and silts with sandy intercalations. Interbeds of black organic clays and silts are clearly distinguishable and point to a swampy environment (Krstić, 2006). Vestalenula valves were collected at $26.6 \mathrm{~m}$.

At Ugrinovci, borehole KG-33 was drilled into the Lower Paludinian Beds. The $114 \mathrm{~m}$ succession is made up of silts and silty sands with sandy laminations (Krstić, 2006). Vestalenula valves were collected at $178.8 \mathrm{~m}$. At Mazgoš, in an open pit near Dimitrovgrad, deposits $5.25 \mathrm{~m}$ above the coal seam were sampled, and the age of these sediments bearing Vestalenula valves is Late Pliocene.

\section{MORPHOMETRIC ANALYSIS}

\section{Methodology}

Four right Vestalenula valves from Tuscany, five right valves from Latium, one right valve from Serbia, three right valves 


\begin{tabular}{lccc}
\hline Fossil Vestalenula species & $\begin{array}{c}\text { Palaeoenvironment and } \\
\text { geographical distribution }\end{array}$ & Age & References \\
\hline
\end{tabular}

\section{danielopoli group}

Vestalenula angulata $\mathrm{n}$. sp.

Vestalenula danielopoli (Martens, Rossetti \& Fuhrmann, 1977)

Vestalenula cf. sp. B Danielopol, 1980

\section{boteai group}

Vestalenula boteai (Danielopol, 1970)

Vestalenula longissima $\mathrm{n} . \mathrm{sp}$

Vestalenula pliocenica $\mathrm{n}$. sp.

Vestalenula $\mathrm{cf}$. $V$. pliocenica $\mathrm{n}$. sp. Vestalenula pagliolii (Pinto \& Kotzian, 1961)

undetermined group

Vestalenula cylindrica (Straub, 1952)

Vestalenula flandrini (Carbonnel, 1985)

Vestalenula sp. Mazzini \&

Sardella, 2004
Oligohaline marsh, Baccinello

Basin (Tuscany, Italy);

Shallow freshwater to oligohaline

lake, Velona Basin (Tuscany,

Italy)

Shallow standing water, fed by

helocrene springs, Mücheln,

Germany

Shallow standing water, fed by

helocrene springs, Ostrau,

Germany

Algarve, Portugal

Bojnice-Opatovce, Slovakia

Colle S. Lorenzo, Fara in Sabina, Italy

Vrisses, Rethymnon Basin, Crete

Mazgos, Serbia

Opatovac village, Danube Island,

Serbia

Čelarevo the G-3 borehole, Serbia

Colle Cigliano, Marcellina, Italy

Velona Basin, Tuscany, Italy

Schönfeld, Germany

Cottbus, Germany

Algarve, Portugal

Sinjskog Polja, Croatia

Hesse, Germany (as Darwinula chatti)

Several localities, Turkey

Sandelzhauten, Germany

Southern German Molasse Basin

Steinheim Basin, southern

Germany

Ehiningen a.d. Donau, southern

Germany

Kythira Island, Greece

Turiec Basin, Slovakia

Stirian Basin, Austria

Eubea Island, Greece

Kos Island, Greece

Algarve, Portugal

Varzaneh region, Iran

Le Locle, Upper Freshwater

Molasse, Switzerland

Momi Plain, Socotra Island,

Yemen early Messinian

early Messinian

Holocene

Holocene

Pleistocene (?Eemian)

present paper

present paper

Martens et al. (1997)

Martens et al. (1997)

Cabral et al. (2005)

Middle Holocene

Late Pliocene

early Tortonian

Late Pliocene

Late Pliocene

Late Pliocene

Late Pliocene

early Messinian

Eemian

Eemian

Pleistocene (?Eemian)

Miocene

Early Miocene

Early Miocene-Early Pleistocene

Middle Miocene

Middle Miocene

Middle Miocene

Middle Miocene

Middle-Late Miocene

Late Miocene

Late Miocene

Late Pliocene

Late Pliocene

Pleistocene (?Eemian)

Holocene

Late Miocene

Quaternary
Martens et al. (1997)

present paper

present paper

present paper

Krstić (1995); present paper

Krstić (2006); present paper

present paper

present paper

Pietrzeniuk (1991)

Martens et al. (1997)

Cabral et al. (2005)

Sokač (1979)

Malz \& Moayedpour, 1973

Freels (1980)

Witt (1998)

Witt (2000)

Lutz (1965); Janz (1997)

Straub (1952)

Mostafawi (1990)

Pipik \& Bodergat (2003); Minati

et al. (2008)

Gross, 2004; Minati et al., 2008

Mostafawi (1994)

Mostafawi (1988)

Cabral et al. (2005); Minati et al.

(2008)

Janz et al. (2001)

Carbonnel et al. (1985)

Mazzini \& Sardella (2004)

Table 2. List of the fossil species of Vestalenula with their geographical location and stratigraphical range.

from Crete and, for comparison, some right valves of Vestalenula cylindrica Straub, 1952 (Straub, 1952; Minati et al., 2008) were analysed. Italian, Serbian and Cretan Vestalenula valves were photographed using a transmitted-light microscope NIKON E-200 and a digital camera NIKON DS-5M. The holotype of $V$. cylindrica was scanned from Straub's (1952) paper, while the data concerning the Austrian population of $V$. cylindrica (Minati et al., 2008) were provided by one of the authors (KM). The pictures of the valves were processed further using TPS-dig software, version 1.37 (Rohlf, 2003), which 


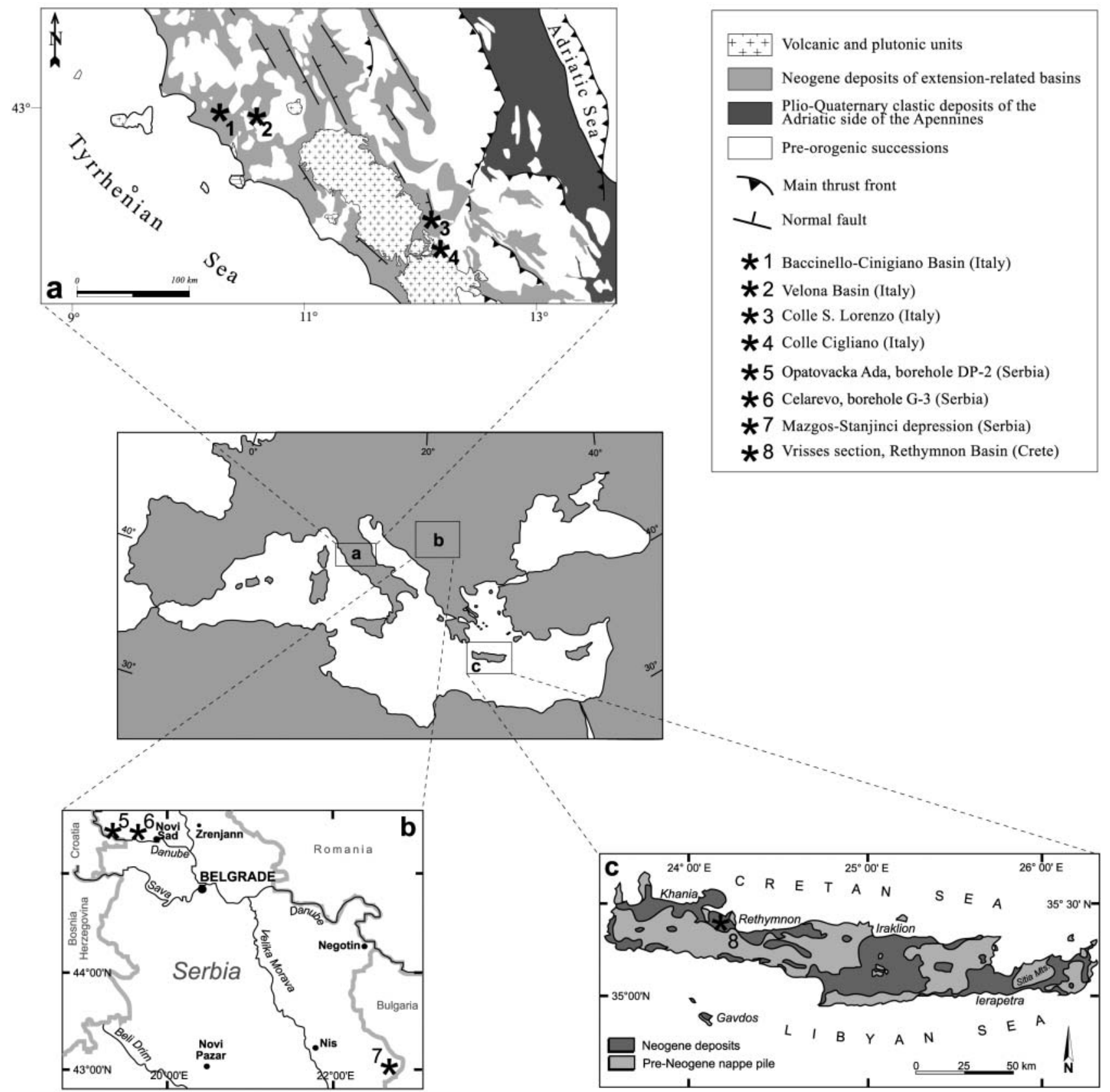

Fig. 1. Location maps of the studied sections.

digitizes outlines (cf. Zelditch et al., 2004). Morphometric analysis of the valves was performed with the software MORPHOMATICA, version 1.6.01 (Brauneis et al., 2006a). For a detailed description of this program and how to use it, see Brauneis et al. (2006b). For the reconstruction of valve outlines, the program MORPHOMATICA uses the B-splines approach adapted to Ostracods by J. Linhart (cf. Baltanás et al., 2003; Brauneis et al., 2006b).

B-splines are piecewise polynomial curves which are able to approximate the various sections of an ostracod outline. MORPHOMATICA uses quadratic B-splines, which permits description of a curve by few parameters, i.e. the coordinates of the so-called 'control points' (Hoschek \& Lasser, 1993). Linhart's algorithm for ostracod description of an outline consists of the approximation of curves for the upper and lower valves separately. The two parts are separated by the $\mathrm{x}$-axis, which crosses the centroid of the digitized points $\mathrm{p}_{1} \ldots \mathrm{p}_{\mathrm{m}}$ of the outline.

To compare the shape of two outlines, they first have to be superimposed. Ideally, this should be done in a way that the 'difference' between them is as small as possible. For this purpose the two outlines are rotated such that the centroids and the main axes of inertia coincide. To avoid differences between valves caused only by valve size, the outlines have to be scaled appropriately. It seems to be most natural to determine the 


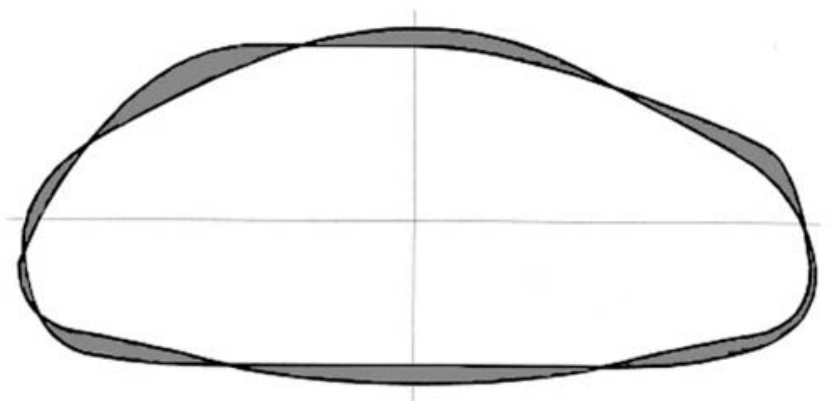

Fig. 2. Area deviation of two ostracod valve outlines (modified after Minati et al., 2008).

scaling factor such that the outlines have an equal area ('normalised for area') (Brauneis et al., 2006b; Minati et al., 2008).

The difference between two superimposed outlines is described easily by the vectors between the corresponding control points (Baltanás et al., 2003; Brauneis et al., 2006b). An innovation in Linhart's algorithm for the description of shapedifferences of ostracod valves consists of the calculation of the area deviation between two superimposed (and previously scaled) outlines (Minati et al., 2008). The 'area deviation' is the area of part of the plane that is inside the first outline and outside the second, or vice versa. Thus, it may be viewed as the area 'between' the two outlines (the shaded region in Fig. 2).

Multivariate statistical analyses of the pairwise differences between Vestalenula shapes were carried out with the computer program PRIMER 6 (Plymouth Routines In Multivariate Ecological Research) (Clarke \& Gorley, 2006). We used Nonmetric Multidimensional Scaling (N-MDS) and the randomization test for difference of groups, ANOSIM (analysis of similarities), for 1-way layout (Clarke \& Warwick, 2001).

The N-MDS is a nonparametric method, which constructs a 'map' of distances reflecting the pairwise dissimilarities of the valve-shape scored. Because these distances are expressed as ranks of dissimilarities and not as absolute differences, no axes are displayed in a N-MDS plot (for the rationale and computation of the N-MDS, see Clarke \& Gorley, 2006). We used this method to demonstrate dissimilarity differences within, and among samples.

The nonparametric test ANOSIM is a permutation/ randomization method that expresses the degree of differences between pairs of samples. It is based on the corresponding rank of similarities between samples. The value of $R$ varies between 0 , when there is no separation between samples, and 1, if samples are completely separated. After Clarke \& Gorley (2001), for $R \geq 0.75$ pairs of samples are well separated; for $R$ between 0.75 and 0.50 , samples are partially overlapping; while, for $\mathrm{R} \leq 0.50$, samples are not separable.

The degree of valve variation within a population was estimated by the mean pairwise distance between 'area deviations'. This is equivalent to the MPD index of Ciampaglio et al. (2001) used by Minati et al. (2008). Basic descriptive statistics, like arithmetic mean, standard deviation, confidence limits and coefficient of variation were calculated with the BIOMstat 3.3 software (Rohlf, 2002).

\section{Results}

After careful observation under the stereomicroscope, the geometric morphometric analysis was applied to five groups of Vestalenula right valves from Serbia, Crete, Tuscany, Latium 1 and Latium 2. There are two forms from Latium as Latium 1 and Latium 2 valves differ considerably in the $L / h$ ratios. The computed mean outlines (normalized for area) of each group were compared with each other (Fig. 3). The Tuscany right valves result is different in shape from any other investigated Vestalenula valves (Figs $3 \mathrm{a}-\mathrm{d}$ ); in particular, it differs from Latium 1 (Fig. 3a), Serbia (Fig. 3c) and Crete (Fig. 3d) with a proportionally more elongated outline, a more pointed anterior border, an arched dorsal margin and a more sinuose ventral border. Furthermore, in comparison with the mean outline of Latium 2 (Fig. 3b), it has a more arched dorsal border, a sinuose ventral margin and a posterior border that is more rounded ventrally. Also the Latium 2 valves differ considerably from the other Vestalenula valves (Figs 3e-g) in their proportionally more elongated outline and more pointed anterior border. On the contrary, the comparison between the Latium 1, Serbia and Crete right valves (Fig. 3h) does not show any relevant statistical difference in shape. Similar conclusions are shown by the dendrogram of the group average linking on Bray-Curtis specimen dissimilarities, and by the non-metric multidimensional scaling (nMDS) plot (Fig. 4). In Figure 4a, at a dissimilarity level of around $68 \%$, two clusters are discriminated, with cluster A including Latium 1, Serbia and Crete valves and cluster B including Latium 2 and Tuscany valves. At a still higher level of dissimilarity (around 53\%), cluster B is further split into subcluster $\mathrm{B}_{1}$ (Latium 2 specimens) and sub-cluster $\mathrm{B}_{2}$ (Tuscany specimens). In Figure $4 \mathrm{~b}$, three different groups are clearly separated, Tuscany, Latium 2 and a third including Latium 1, Serbia and Crete valves. In conclusion, the geometric morphometric analysis suggests three different Vestalenula taxa among the studied material. The same conclusions can be traced from the ANOSIM pairwise test (Table 3), even if the number of each tested sample is low.

Minati et al. (2008) carried out geometric morphometric analyses on several populations of the fossil species Vestalenula cylindrica (Straub, 1952) from the Late Miocene of Austria and Slovakia, and from the Pleistocene of Portugal. In the present paper a geometric morphometric comparison between the mean outline of the Austrian population (the more statistically representative) and the outline of the $V$. cylindrica holotype (from Straub, 1952) shows their similarity (Fig. 5). Thus, Minati et al. (2008) morphometric data were used to compare our Vestalenula valves with $V$. cylindrica. The results are illustrated in Figure 6, in which it is possible to identify that the Tuscany valves show remarkable differences (Fig. 6a), Latium 2 is slightly more elongated [as in the Portuguese population of $V$. cylindrica (Minati et al., 2008, fig. 9B)] but shows a more tapered anterior border (Fig. 6c), whilst Latium 1, Serbia and Crete mean outlines are slightly stouter than $V$. cylindrica (Fig. 6b). Additionally, when the development of the ventral keel in the right valve is taken into consideration, $V$. cylindrica shows a more elongated keel than the Latium 1, Serbia and Crete specimens.

Taking into account all of these considerations, we ascribe the Vestalenula valves analysed in this paper to three new species, namely Vestalenula pliocenica n. sp (Latium 1, Serbia 

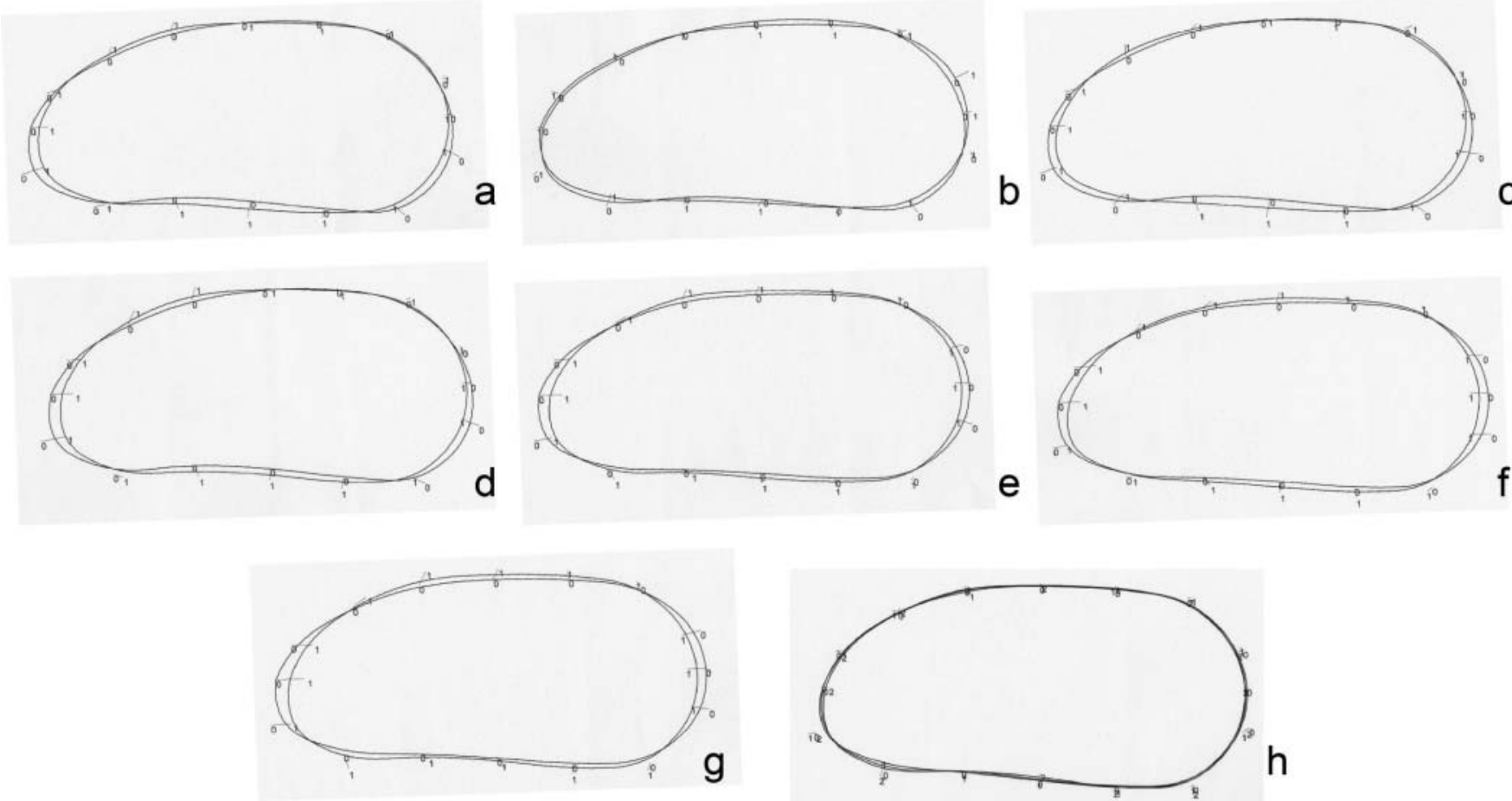

Fig. 3. Comparison of the mean outlines (normalized for areas) of the right valve among the Vestalenula groups. (a) Tuscany versus Latium 1; (b) Tuscany versus Latium 2; (c) Tuscany versus Serbia; (d) Tuscany versus Crete; (e) Latium 2 versus Latium 1; (f) Latium 2 versus Serbia; (g) Latium 2 versus Crete; (h) Latium1 versus Serbia and Crete.

and Crete), Vestalenula angulata n. sp. (Tuscany) and Vestalenula longissima $\mathrm{n}$. sp. (Latium 2), described in the following taxonomic section.

\section{SYSTEMATIC DESCRIPTIONS}

With the exception of the Serbian material, all the Vestalenula valves described in this paper are stored in the Gliozzi's Ostracod Collections, Dipartimento di Scienze Geologiche, Università Roma Tre.

Suborder Darwinulocopina Sohn, 1988 Superfamily Darwinuloidea Brady \& Norman, 1889

Family Darwinulidae Brady \& Norman, 1889

Genus Vestalenula Rossetti \& Martens, 1998

Vestalenula angulata $\mathrm{n} . \mathrm{sp}$.

(Pl. 1, figs 1-14)

2002 Darwinula cylindrica Straub; Ghetti et al.: 8, table 2.

2004 Darwinula; Benvenuti et al.: 18.

2006 Vestalenula angulata $\mathrm{n}$. sp.; Ligios et al.: 51 (nomen nudum). 2008 Vestalenula sp.; Ligios et al.: 277, 280-284, 286.

Derivation of name. The name angulata refers to the sharp postero-ventral angle on the right valve, underlined by the prominent postero-ventral keel.

Diagnosis. Small-sized Vestalenula with inclined and infracurvated anterior margin and angulated postero-ventral margin.
Holotype. Right adult valve ( $L=0.47 \mathrm{~mm} ; H=0.21 \mathrm{~mm})$, G.O.C. M75/3/11, Dipartimento di Scienze Geologiche, Università Roma Tre. Illustration: Plate 1, figs 1-2.

Paratypes. 1 adult carapace (G.O.C. M108/1/1), 2 left adult valves (G.O.C. T23/1 and lost valve) and 2 right adult valves (G.O.C. M75/3/12, G.O.C M116/2/1).

Material. Sample BA61: 1 adult carapace, 1 instar; sample BA74: 1 adult carapace, 2 left valve, 4 right valves and 7 juveniles carapace; sample BA75: 1 left valve, 4 right valves and 7 instars; sample BA80: 1 carapace, 1 right valve and 6 instars.

Locality and horizon. Baccinello-Cinigiano Basin (Tuscany, Italy), sample BA74, Ribaldella 2 section.

Age. Mammal level V3, early Messinian.

Description. A new species of Vestalenula referable to the danielopoli group for the long postero-ventral keel $(22 \%$ of the total length) on the right valve. Small-sized carapace with pointed anterior and rounded posterior ends; in ventral view the postero-ventral keel is not visible because the left valve widely overlaps the right one; shell rather thick. In lateral outer view, the right valve is rather elongated; gently arched dorsal margin, which bends anteriorly, underlining a pointed, infracurvated anterior margin; ventral margin straight in the posterior portion and sinuose in the anterior; posterior margin widely rounded; postero-ventral margin angulated owing to the presence of the keel; left valve stouter; gently arched horizontal dorsal margin; 


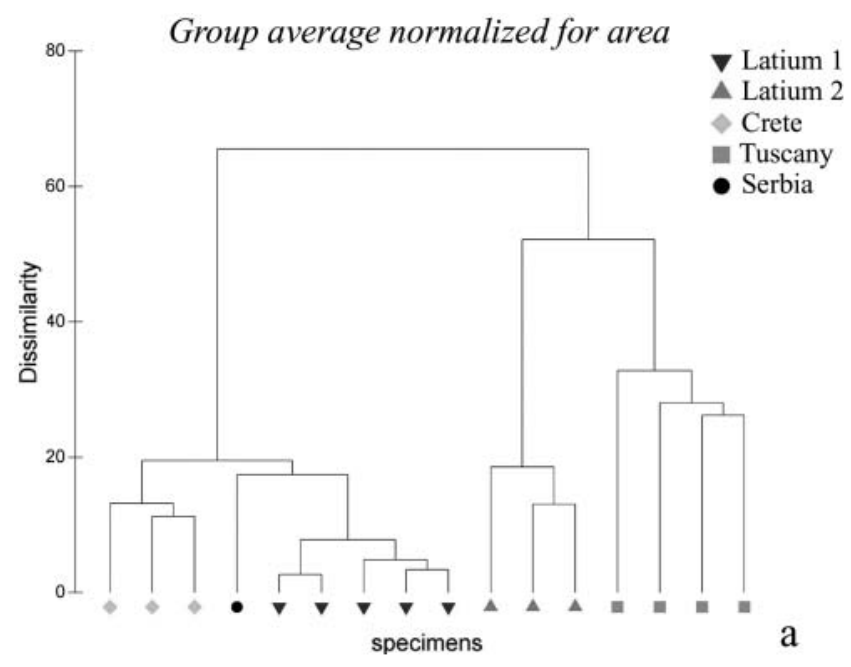

n-MDS normalized

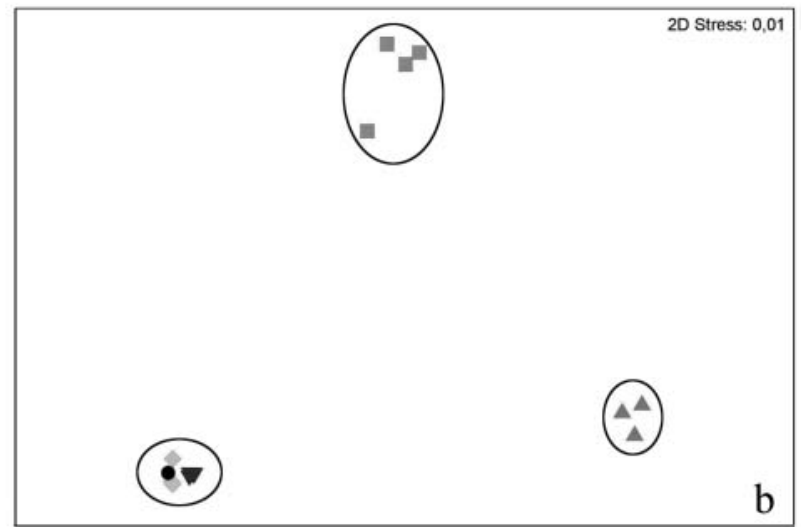

Fig. 4. (a) Dendrogram of the group average linking on Bray-Curtis specimen dissimilarities (normalized for area). (b) Non-metric multidimensional scaling plot (n-MDS) in 2D morphological space (normalized for area).

\begin{tabular}{lcc}
\hline Groups & $R$ statistic & Significance level (\%) \\
\hline Latium1, Latium2 & 1 & 10 \\
Latium1, Crete & 0.5 & 20 \\
Latium1, Tuscany & 1 & 6.7 \\
Latium2, Crete & 1 & 10 \\
Latium2, Tuscany & 1 & 2.9 \\
Crete, Tuscany & 0.685 & 2.9
\end{tabular}

Table 3. ANOSIM pairwise tests among groups of Vestalenula from Latium, Tuscany and Crete.

anterior margin rectilinear and inclined forwards in the dorsal portion and then rounded; posterior margin less rounded than in the right valve. In lateral inner view, the right part of the hinge adont with two remarkable thicknesses in correspondence of the cardinal angles.

Dimensions. Right valve: $L=0.44-0.49 \mathrm{~mm} ; H=0.20-0.23 \mathrm{~mm}$; left valve: $L=0.46-0.49 \mathrm{~mm} ; H=0.19-0.23 \mathrm{~mm}$.

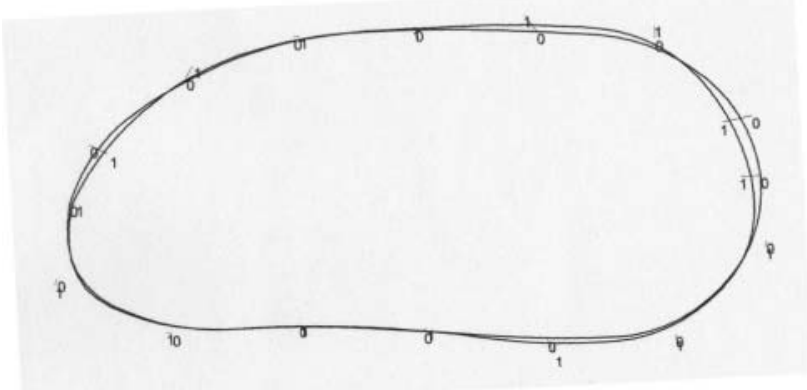

Fig. 5. Comparison of the mean outline (normalized for areas) of the right valve between Vestalenula cylindrica from Austria and Vestalenula cylindrica holotype (the holotype outline is from Straub, 1952, fig. 19).
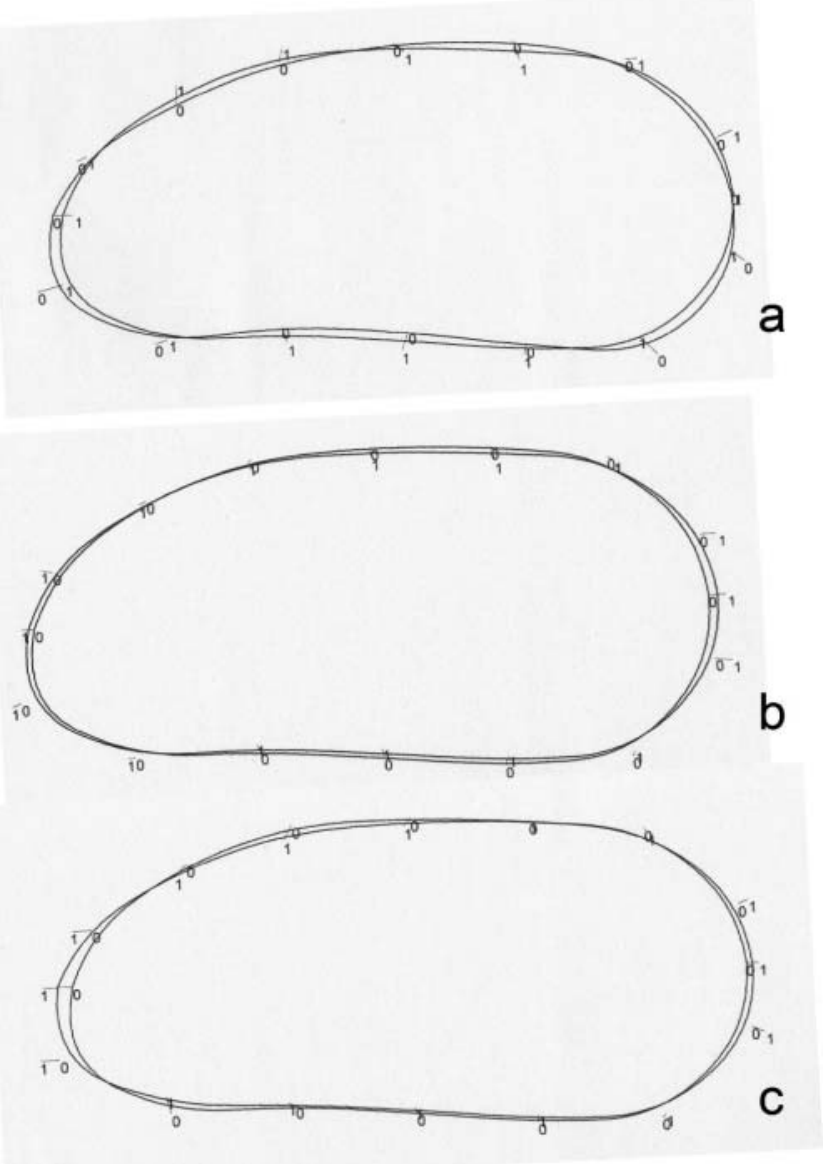

Fig. 6. Comparison of the mean outlines (normalized for areas) of the right valve between Vestalenula groups and Vestalenula cylindrica. (a) Tuscany versus V. cylindrica; (b) Latium 1, Serbia, Crete versus V. cylindrica. (c) Latium 2 versus $V$. cylindrical.

Stratigraphic range/occurrence. The species has also been found at the Velona Basin, (Tuscany) in the Fosso Casotto section [sample 2: 1 carapace, 1 right valve and 1 instar; sample 36: 1 instar; sample 59: 1 left valve], aged early Messinian (Ghetti et al., 2002). 


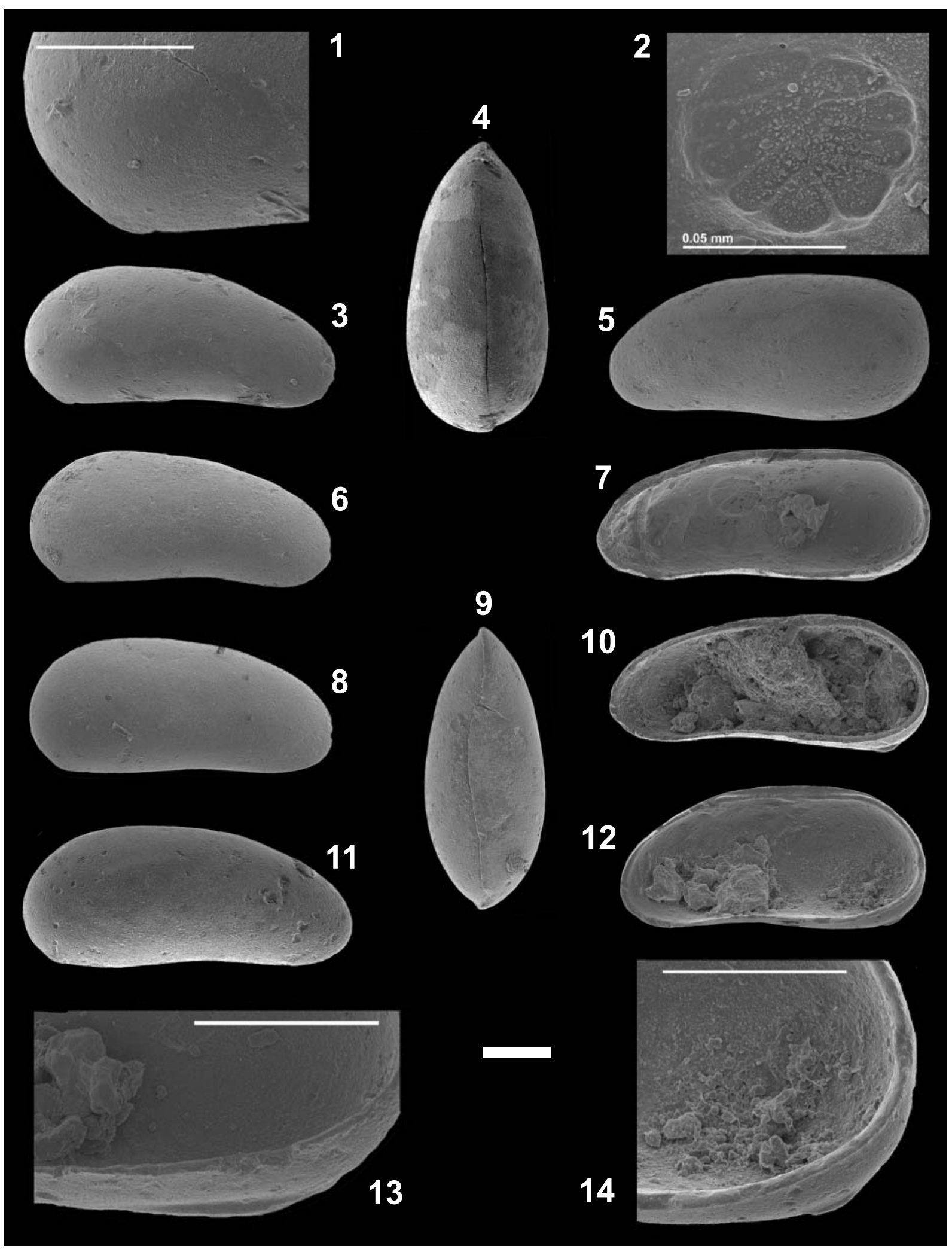


Remarks. The only recovered left valve is infilled with sediment so it is impossible to observe the morphology and the position of the antero-ventral tooth.

Comparisons. At present, four species of Vestalenula referable to the danielopoli group are known: $V$. danielopoli (Martens, Rossetti \& Furhmann) 1997, from the Holocene of Germany, $V$. matildae Martens \& Rossetti, 2002, living in northwestern Australia, V. cornelia Smith, Kamiya \& Horne, 2006, living in Japan and the Ogasawara Islands and V. carveli Artheau, 2007 living in southern France, whilst V. cylindrica (Straub, 1952) displays puzzling characters, having a rather elongated keel and a narrow internal tooth (Cabral et al., 2005). This latter species is known only as a fossil from the Miocene-Pleistocene of western Europe [Portugal (Cabral et al., 2005)], central Europe [Germany, Switzerland, Austria, France and Slovakia (Straub, 1952; Lutz, 1965; Malz \& Moayedpour, 1973; Carbonnel et al., 1985; Janz, 1997; Pipik \& Bodergat, 2003; Gross, 2004; Minati et al., 2008)], southeastern Europe [Greece (Mostafawi, 1988, 1990, 1994)] and western Asia [Turkey and Iran (Freels, 1980; Janz et al., 2001]. V. matildae, $V$. cornelia and $V$. carveli are smaller than $V$. angulata n. sp., while $V$. danielopoli and $V$. cylindrica show the same size-range. $V$. angulata n. sp. differs from $V$. danielopoli in having a generally more elongated outline, a more angulated postero-ventral margin and a more arched dorsal margin, whilst it differs from $V$. cylindrica in having a more angulated postero-ventral margin, a more pointed and infracurvated anterior margin and a more arched dorsal margin.

Palaeoecology. At Velona (Ghetti et al., 2002) and BaccinelloCinigiano basins (Ligios et al., 2008), V. angulata n. sp. occurs together with both freshwater and oligo-mesohalophile species (Paralimnocythere sp., Candona (Neglecandona) neglecta Sars, 1887, Pseudocandona sp., Ilyocypris gibba Ramdohr, 1808, Ilyocypris sp., Cypridopsis cucuroni Carbonnel, 1969, Potamocypris gracilis Sieber, 1905, Loxoconchissa (Loxocaspia) nuda Faranda, Gliozzi \& Ligios, 2007, Cyprideis spp., Tavanicythere lepida Bossio, 1980 and Amnicythere sp.). According to Ligios et al. (2008), V. angulata n. sp. (=Vestalenula sp.) can be considered a shallow-water dweller, being oligothermophilic, oligohalophile and rheoeuryplastic.

Vestalenula longissima $\mathrm{n} . \mathrm{sp}$. (Pl. 2, figs 1-8; Pl. 3, fig. 15)

Derivation of name. The name reflects the large dimensions, coupled with the elongated outline.

Diagnosis. A new species of Vestalenula referable to the boteai group for the short postero-ventral keel (13\% of the total length) on the right valve. Large-sized carapace with pointed anterior and rounded posterior ends. In lateral outer view, the right valve is elongated; gently arched dorsal margin, which bends anteriorly, underlining a pointed anterior border; ventral margin straight; posterior margin widely rounded; postero-ventral border angulated, owing to the presence of the keel; left valve stouter; gently arched horizontal dorsal border; rounded anterior and posterior borders. Both valves show the presence of large normal pore-canals confined in the anterior and posterior areas. In lateral inner view the right hinge adont with two feeble thicknesses in correspondence of the cardinal angles. Juveniles are characterized by two small ventral teeth in the left valve.

Holotype. Right valve ( $L=0.51 \mathrm{~mm} ; H=0.22 \mathrm{~mm}$ ), (G.O.C. M112/1/2), Dipartimento di Scienze Geologiche, Università Roma Tre.

Paratypes. 1 carapace (G.O.C. M116/1/1), 4 right valves (G.O.C. T24/1; G.O.C. M112/1/1, G.O.C. 116/1/2, G.O.C. 116/1/6), 1 left valve (G.O.C. M112/1/5).

Material. Colle S. Lorenzo [Fara in Sabina (Rieti, central Italy)], borehole ARI1LGT19, sample 10: 1 carapace, 9 right valves, 1 left valve and 19 instars; Colle S. Lorenzo [Fara in Sabina (Rieti, central Italy)], borehole ERI1LGT18, sample 5: 1 right valve and 1 instar; Colle Cigliano [Marcellina (Roma, central Italy)], sample PBS1: 1 right valve.

Locality and horizon. Colle S. Lorenzo [Fara in Sabina (Rieti, central Italy)], borehole ARI1LGT19, sample 10.

Age. Late Pliocene.

Dimensions. Right valve: $L=0.50-0.52 \mathrm{~mm} ; H=0.21-0.22 \mathrm{~mm}$; left valve: $L=0.54 \mathrm{~mm} ; H=0.24 \mathrm{~mm}$.

Stratigraphic range/occurrence. The species has also been found in borehole ERI1LGT18, sample 5 and at Colle Cigliano, sample PBS1, dated as Late Pliocene.

Comparisons From its large size, V. longissima n. sp. could be comparable only with Vestalenula daps (Harding, 1962) which is much larger and less elongated. Among the species included in the boteai group, only V. boteai (Danielopol, 1970) and V. lundi (Neale \& Victor, 1978) show a rather elongated shape, but the outline differs greatly and they are smaller. In comparison with the fossil species $V$. cylindrica, $V$. longissima $\mathrm{n}$. sp. is of a larger size, has a shorter keel, more elongated proportions and a more tapered anterior border. This is evidenced also by the $H_{\mathrm{a}} / L$ ratio,

\section{Explanation of Plate 1.}

figs 1-14. Vestalenula angulata $\mathrm{n}$. sp.: 1, detail of the posterior area of the right valve illustrated in external view in fig. $3 ; \mathbf{2}$, detail of the central muscle scars of the right valve illustrated in fig. 7; 3, external lateral view of a right valve, holotype (G.O.C. M75/3/11), sample BA 74; 4, dorsal view of a carapace, paratype (G.O.C. M108/1/1), sample BA 74; 5, external lateral view of a left valve, paratype (G.O.C. T23/1), sample BA 74; 6, external lateral view of a right valve (G.O.C. M75/3/11), sample BA 80; 7, internal lateral view of a right valve, paratype (G.O.C. M75/3/12), sample BA 74; 8, external lateral view of a right valve (lost specimen), sample VE 2; 9, ventral view of a carapace (G.O.C. M100/1/8), sample BA 61; 10, internal lateral view of a right valve, paratype (G.O.C. M75/3/12), sample BA 74; 11, external view of a right valve, paratype (G.O.C. M116/2/1), sample BA 74; 12, internal view of the right valve illustrated in fig. 11; 13, detail of the posterior area of the right valve illustrated in internal view in fig. 7; 14, detail of the posterior area of the right valve illustrated in fig. 12. White bar corresponds to $0.1 \mathrm{~mm}$. 
S. Ligios et al.

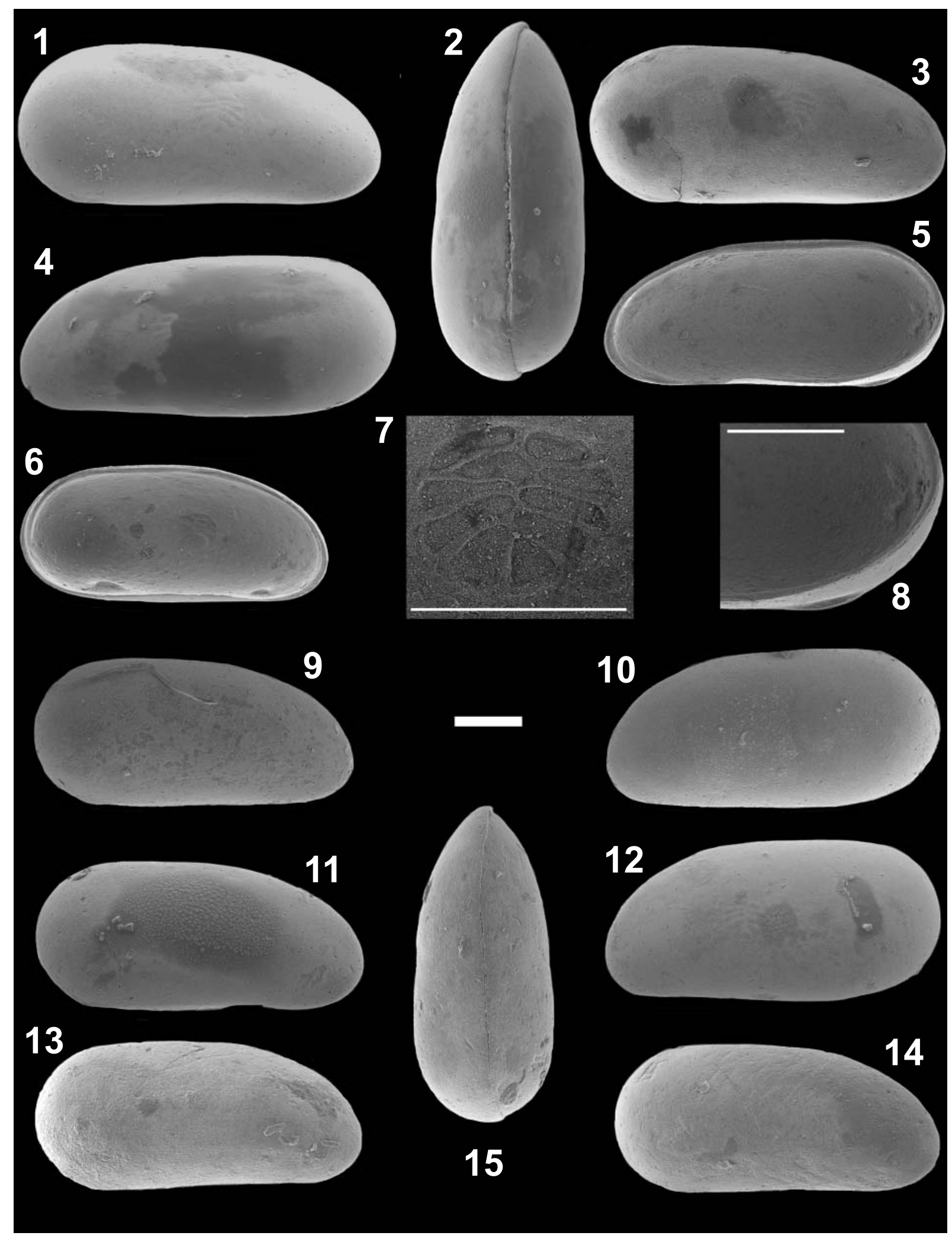


where $H_{\mathrm{a}}$ is the valve anterior height measured at $1 / 6$ of the length. This index is 32.6 in $V$. longissima, 34.2 in the elongated valves of $V$. cylindrica from Boliqueime (Portugal) and 35.6 for the Austrian population of $V$. cylindrica.

Palaeoecology. In both the borehole samples, $V$. longissima n. sp. was recovered in association only with freshwater taxa [Candona (Candona) sp., Pseudocandona marchica (Hartwig), Cyclocypris ovum (Jurine), Ilyocypris gibba (Ramdohr), Ilyocypris cf. I. getica Masi, Cypris cf. C. pubera Müller and Cypridopsis vidua (Müller)]. At Colle Cigliano only one valve was recovered together with very scarce Cyprideis torosa.

Vestalenula pliocenica $\mathrm{n} . \mathrm{sp}$

(Pl. 2, figs 9-15; P1. 3, figs 1-11, 13-14)

1989 Darwinula cylindrica Straub; Mostafawi: Pl. 4, fig. 16. 1995 Darwinula cf. boteai Danielopol; Krstić: 405, text-fig. 9. 2006 Vestalenula pliocenica Ligios et al:: 51 (nomen nudum). 2006 Vestalenula sabinae Ligios et al.: 51 (nomen nudum). 2006 Vestalenula pliocenica Ligios, Gliozzi \& Krstić; Krstić: 202-203, pl. 65, fig. 9; pl. 67, fig. 15; pl. 70, fig. 13 (nomen nudum).

Derivation of name. From Pliocene, the stratigraphic interval in which the species was first found.

Diagnosis. A new species of Vestalenula referable to the $V$. boteai group for the short postero-ventral keel (around $14-15 \%$ of the total length) on the right valve. Carapace pointed at the anterior end, and rounded posteriorly. In lateral view, the valves shows an elongated and low outline, even if rather variable, with a dorsal margin, which runs parallel to the ventral one until 2/3 of the length and then bends anteriorly, joining an infracurvated anterior margin. Ventral margin always straight in the posterior portion and sometimes sinuose in the anterior one. Posterior margin widely rounded. In the right valve, a postero-ventral keel is present, short and slightly shifted anteriorly. In inner view, the right adont hinge is characterized by two remarkable thicknesses in correspondence of the cardinal angles. The inner left valve is characterized by a subtriangular antero-ventral tooth.

Holotype. Right valve $(L=0.48 \mathrm{~mm} ; H=0.22 \mathrm{~mm})$, G.O.C. M52/ $1 / 3$, Natural History Museum, Belgrade.

Paratype. 1 right valve and 2 left valves (G.O.C. M52/1/1).
Material. Sample $2 \mathrm{~m}$ above the coal: 17 adult valves and 8 moults; sample $3 \mathrm{~m}$ above the coal: 21 adults; sample $5.25 \mathrm{~m}$ above the coal: 2 adults and 3 juveniles.

Locality and horizon. Mazgos, $2 \mathrm{~m}$ above the coal level.

Age. Late Pliocene (Middle Paludinian Beds).

Dimensions. Right valve: $L=0.48-0.51 \mathrm{~mm} ; H=0.22-0.23 \mathrm{~mm}$; left valve: $L=0.46-0.51 \mathrm{~mm} ; H=0.22-0.23 \mathrm{~mm}$.

Stratigraphic range/occurrence. In Serbia, Vestalenula pliocenica n. sp. has also been collected from the Lower-Middle Paludinian Beds of DP-2 borehole (Opatovac village, Danube island) at $72.0 \mathrm{~m}$ (Krstić, 1995), in the Middle Paludinian Beds of G-3 borehole at $26.6 \mathrm{~m}$ (borehole G-3) and in the Lower Paludinian beds of KG-33 borehole (Ugrinovci village, north of Belgrade) at $178.8 \mathrm{~m}$. The species has also been collected outside the type locality in Crete (Greece) and Italy. In Crete, $V$. pliocenica was collected in the Tortonian section of Vrysses from sample KR10 with 3 adult carapaces, 10 adult valves, 17 instars. In Italy, valves of $V$. pliocenica were recovered from the Upper Pliocene (Gelasian) Colle Ciliano section, Latium (sample PBS1: 14 adult valves), Colle S. Lorenzo ARI1LGT19 borehole, Latium (sample 10: 2 adult valves) and possibly from the Velona Basin (Tuscany), section Orcia W2 (Early Messinian): sample OW2-1: 2 adult valves and 2 instars. These latter specimens show a slightly different shaped posterior border. Thus, the general stratigraphical range of the species is Tortonian-Pliocene.

Comparisons. So far, the $V$. boteai group includes several Vestalenula species. The relatively elongated and anteriorly shifted ridge of Vestalenula pliocenica n. sp. makes this species comparable with $V$. marmonieri Rossetti \& Martens, 1999 (from New Caledonia), from which it differs in a more oval outline and in a less inclined dorsal border. A similar outline is shared with Vestalenula sp. C. Rossetti \& Martens, 1999 (from Israel), but this latter form shows a more sinuous ventral margin. Even $V$. molopoensis and $V$. pagliolii seem to be rather similar to $V$. pliocenica $\mathrm{n}$. sp., although their dorsal borders bend inwards; the first is only slightly stouter, its keel is smaller, angulated and more protruding and the brood cavity in the right valve is deeper, while the second shows a more rounded posterior border and, in the left valve, the anterior cardinal angle is not visible. $V$. pliocenica $\mathrm{n}$. sp. differs from $V$. cylindrica in elongated proportions and in the shorter keel that is shifted further backwards.

Explanation of Plate 2.

figs 1-8. Vestalenula longissima $\mathrm{n}$. sp.: 1, external lateral view of a right valve, holotype (G.O.C. M112/1/2), sample ARI1LGT19-10; 2, carapace in dorsal view, paratype (G.O.C. M116/1/1), sample ARI1LGT19-10; 3, external lateral view of a right valve (G.O.C. M108/1/2), sample ERI1LGT18-5; 4, external lateral view of a left valve, paratype (G.O.C. M112/1/5), sample ARI1LGT19-10; 5, internal lateral view of a right valve, paratype (G.O.C. M116/1/2), sample ARI1LGT19-10; 6, internal lateral view of a left juvenile valve (G.O.C. M112/1/3) sample ARI1LGT19-10; 7, detail of the central muscle scars of the right valve illustrated in fig. $5 ; \mathbf{8}$, detail of the posterior area of the right valve illustrated in internal view in fig. 5. figs 9-15. Vestalenula pliocenica $\mathrm{n}$. sp.: 9, external lateral view of a right valve, holotype (G.O.C. M52/1/3), Mazgoš (Serbia), sample $2 \mathrm{~m}$ above the coal; 10, external lateral view of a left valve, paratype (G.O.C. M52/1/1), Mazgoš (Serbia), sample $2 \mathrm{~m}$ above the coal; 11, external lateral view of a right valve, Latium (Italy), sample PBS 1; 12, external lateral view of a left valve, Latium (Italy), sample PBS 1; 13, external lateral view of a right valve, Vrisses (Crete), sample KR10; 14, external lateral view of a right valve, Vrisses (Crete), sample KR10; 15, carapace in dorsal view, Vrisses (Crete), sample KR10. White bar corresponds to $0.1 \mathrm{~mm}$. 


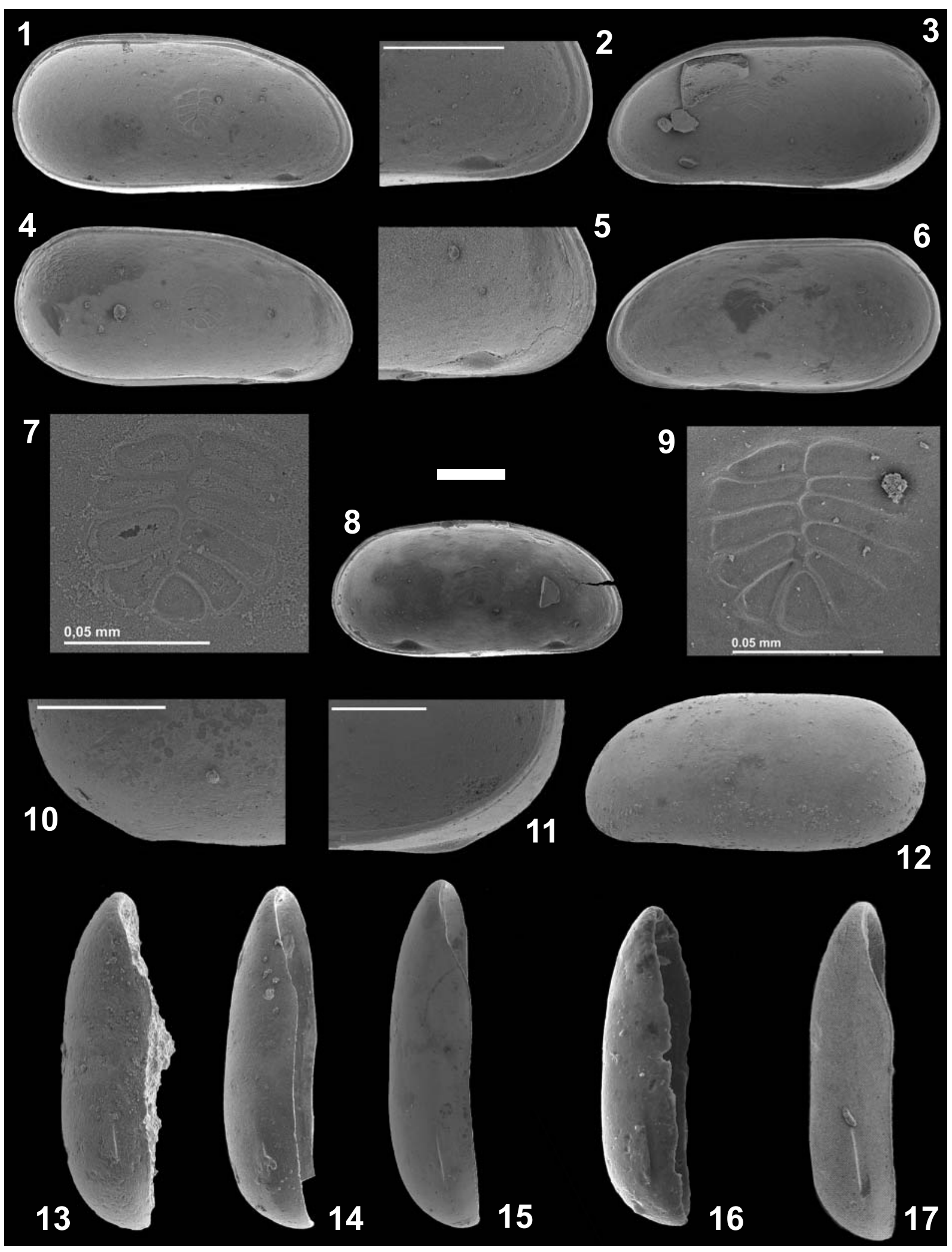


Palaeoecology. Vestalenula pliocenica n. sp. was found with a great number of specimens in the westernmost reaches of the Kujalnician facies in the Balkan Peninsula, at Mazgos at the Serbian/Bulgarian boundary. Together with it, halofile species such as Heterocypris salina (Brady, 1868) and Neglecandona angulata decimai (Freels, 1980) were collected, indicating brackish conditions. A single, probably juvenile, specimen was found in the Middle Danube Plain (Paludinian facies) associated only with halotolerant ostracods. At Colle Ciliano, Italy the species was collected in association with dominant Candona (Candona) sp., subordinated Cyprideis torosa (Jones) and Paralimnocythere relicta (Lilljeborg). Thus, Vestalenula pliocenica $\mathrm{n}$. sp. seems to be a shallow freshwater-oligohaline form.

\section{DISCUSSION AND CONCLUSIONS}

\section{Morphological remarks}

In their revision of the Family Darwinulidae, Rossetti \& Martens (1998) included the extant species within five genera; Darwinula Brady \& Robertson, 1870, Alicenula Rossetti \& Martens, 1998, Vestalenula Rossetti \& Martens, 1998, Penthesilenula Rossetti \& Martens, 1998 and Microdarwinula Danielopol, 1968 [according to Krstić (2006) junior synonym of Sinodarwinula Lee, 1961]. They can easily be distinguished on the basis of the soft parts, but characterization is less easy when only shells are preserved. For example, Darwinula and Alicenula are distinguished mainly by the dimensions of the adult carapace. When only instars are found, it is impossible to ascribe the specimens to either genus. Adults of Vestalenula and Penthesilenula show different carapace characters, Vestalenula is characterized by its greater size, a postero-ventral keel on the right valve and one antero-ventral internal tooth in the left valve, whilst Penthesilenula lacks the postero-ventral keel and bears two internal teeth. However, when only instars are found, the separation of the two genera becomes impossible, as young Vestalenula left valves bear two internal teeth (Freels, 1980, pl. 1, fig. 3; Smith et al., 2006, fig. 1i; Pl. 2, fig. 6; Pl. 3, fig. 8 of our paper) in the same position as species in the Penthesilenula africana group. Moreover, recently, Smith et al. (2006) described three adult male valves of Vestalenula cornelia which are smaller in size than the female (size comparable with A-1 female of Vestalenula or with small Penthesilenula species), bear two internal teeth and lack the postero-ventral keel on the right valve. Thus, unless the genital scars on the carapace are preserved, possible fossil Vestalenula males will probably be misidentified as Vestalenula instars, or as Penthesilenula.
As Vestalenula is a conservative genus with regard to morphology of the soft parts (Rossetti \& Martens, 1999), the carapace and valve features are the main characters for the specific identification. Owing to the asexual reproduction of this genus (males of Vestalenula have been found only for $V$. cornelia and it is not proved that they were functional; Smith et al., 2006; Schön \& Martens, 2007), even small morphological differences in the shells can be retained as diagnostic features at the specific level (Rossetti \& Martens, 1998). This is the case in the differences between $V$. pliocenica $\mathrm{n}$. sp. and $V$. cylindrica, which seem to be separated only by the different length and position of the keel.

\section{Palaeoecological remarks}

The autoecology of living Vestalenula is poorly known. Extant species have been recovered both in interstitial (also phreatic) and spring habitats, connected with riverine, palustrine and hypogean environments. Generally, these are relatively seasonally stable environments, particularly as far as water temperature is concerned, which depends mainly on the geographical location of the site (altitude and latitude). Apart from a few species [V. boteai (Romania), V. cornelia (Japan) and Vestalenula sp. B (Tunisia)], the majority of the known extant Vestalenula are distributed in the Southern Hemisphere, mainly at low latitudes. Water temperature values are provided only for Vestalenula sp. A from Cuba $\left(22.4^{\circ} \mathrm{C}\right), V$. cuneata from Kenya $\left(29^{\circ} \mathrm{C}\right)$ (Danielopol, 1980) and $V$. carveli from southern France $\left(14-22^{\circ} \mathrm{C}\right.$ ) (Danielopol et al., 2009). The latter authors observed a difference of around $12 \%$ in size between normal temperature specimens of $V$. carveli and warm spring specimens. Martens et al. (1997) consider the European fossil remains of $V$. pagliolii and $V$. danielopoli as exotic species, which migrated into Europe during Quaternary warm periods. Very few data concern water salinity, generally it seems that extant Vestalenula populate freshwater habitats (riverine pools and lakes), but at least $V$. daps has been recovered from Lake Te-Nggano (Solomon Islands) at a salinity around 4.56\% (Rossetti \& Martens, 1998). Fossil Vestalenula present more information: $V$. pagliolii from the Eemian of Germany, $V$. angulata n. sp. from the Early Messinian of Italy, $V$. cylindrica from the Middle MioceneQuaternary of Europe and the Middle East and $V$. pliocenica from several Miocene-Pleistocene localities (Table 4) were recovered either with freshwater or oligo-mesohaline forms.

\section{ACKNOWLEGEMENTS}

The authors are very grateful to Dan Danielopol for interesting discussions and valuable suggestions that definitely improved

\section{Explanation of Plate 3.}

figs 1-11, 13-14. Vestalenula pliocenica $n$. sp.: 1, internal lateral view of a left valve, paratype (G.O.C. 52/1/1), Mazgoš (Serbia), sample 2 m above the coal; 2, detail of the anterior area of the left valve illustrated in internal view in fig. 1; 3, internal lateral view of a right valve, paratype (G.O.C. M52/1/1), Mazgoš (Serbia), sample $2 \mathrm{~m}$ above the coal; 4, internal lateral view of a left valve, Latium (Italy), sample PBS 1; 5, detail of the anterior area of the left valve illustrated in internal view in fig. 4; 6, internal lateral view of a right valve, Latium (Italy), sample PBS 1; 7, detail of the central muscle scars of the left valve illustrated in fig. 4. 8, internal lateral view of a left juvenile valve, sample PBS $1 ; \mathbf{9}$, detail of the central muscle scars of the left valve illustrated in fig. 1; 10, detail of the posterior area of the right valve illustrated in external view in Plate 2, fig. 9; 11, detail of the posterior area of the right valve illustrated in internal view in fig. 3; 13, ventral view of a right valve, Vrisses (Crete), sample KR 10; 14, ventral view of a right valve, Latium (Italy), sample PBS 1. fig. 12. Vestalenula $\mathrm{cf}$. V. pliocenica $\mathrm{n}$. sp., external lateral view of a left valve Velona Basin (Tuscany), sample OW2-1. fig. 15. Vestalenula longissima $\mathrm{n}$. sp., ventral view of a right valve, paratype (G.O.C. M112/1/1) sample ARI1LGT19-10. fig. 16. Vestalenula angulata $\mathrm{n}$. sp., ventral view of a right valve. fig. 17. Vestalenula cylindrica Straub, ventral view of a right valve (from Janz, 1997). White bar corresponds to $0.1 \mathrm{~mm}$. 


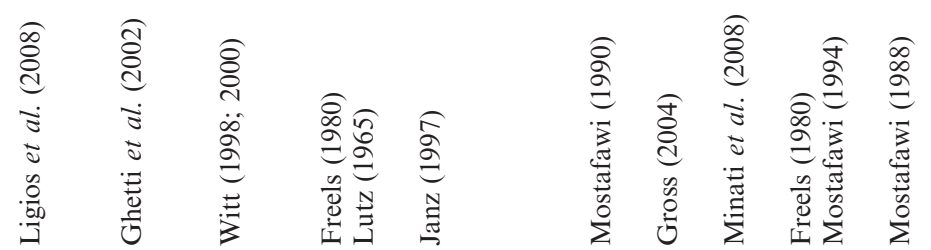

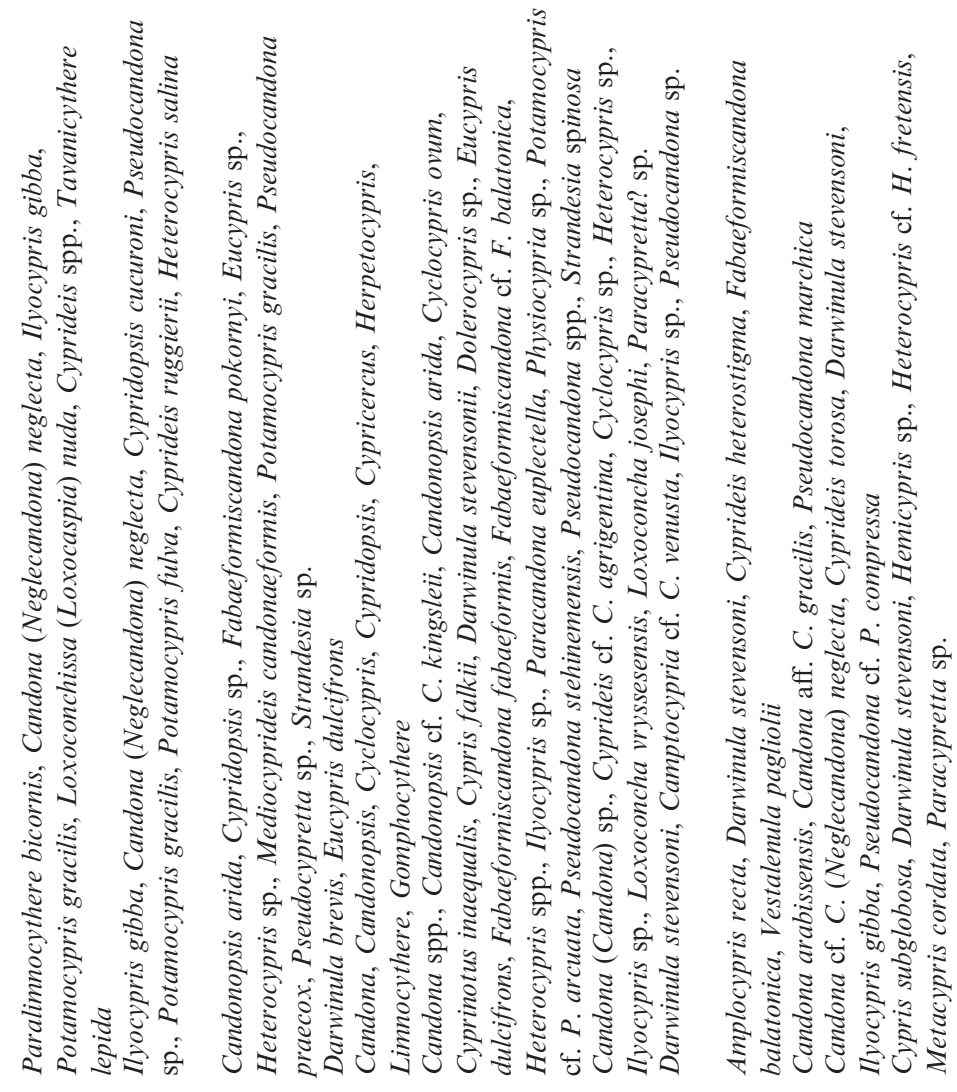

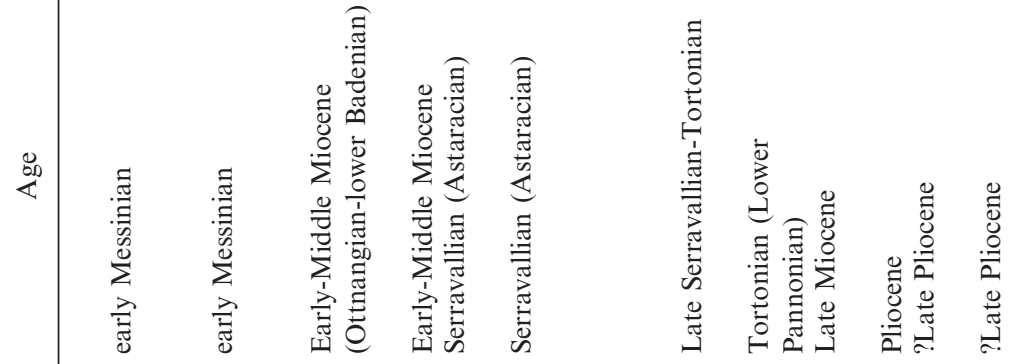

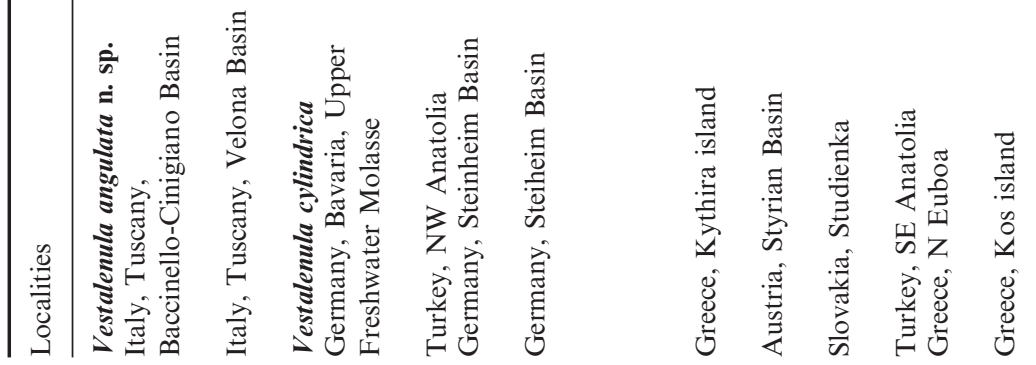


Vestalenula in the Neogene of Italy, Crete and Serbia

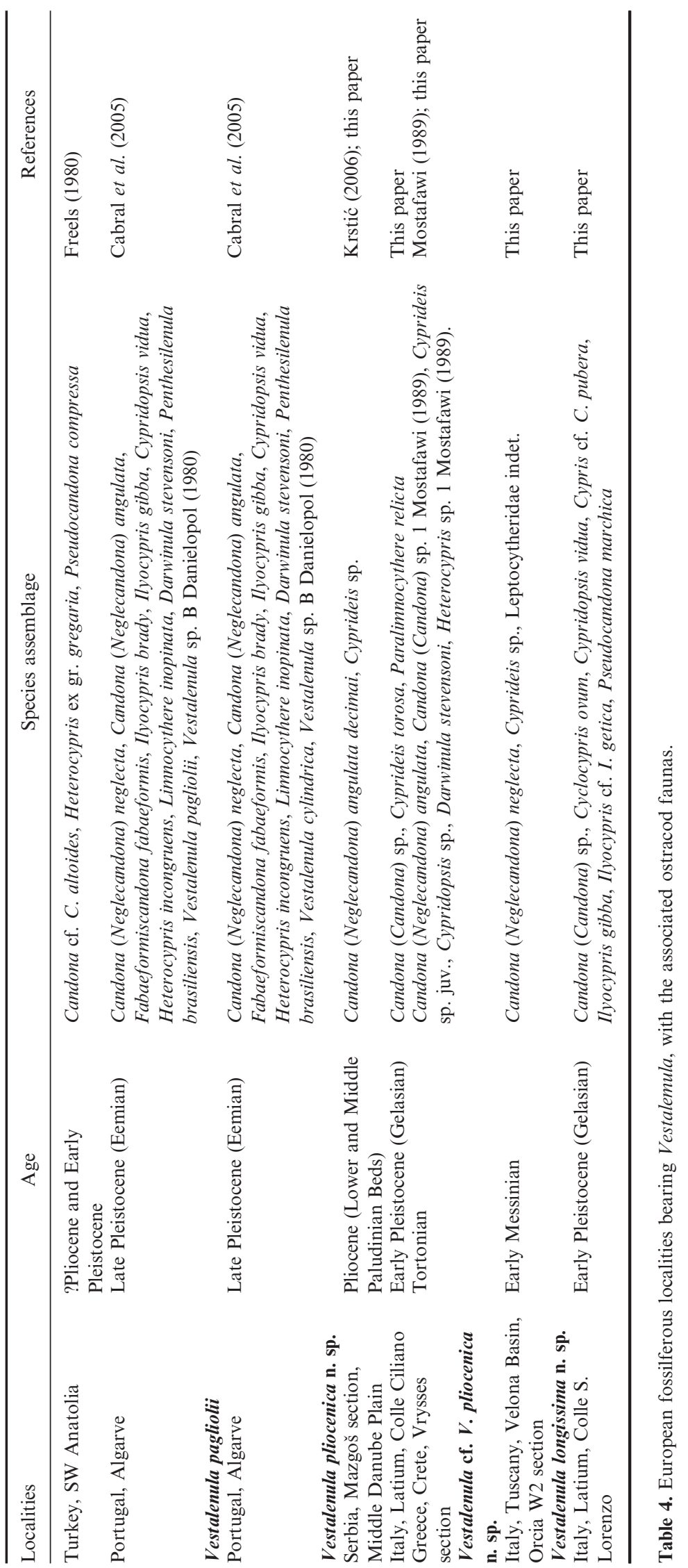


their research. Many thanks to Dan Danielopol, Martin Gross and Werner Piller who organized the workshop 'Methods in Ostracodology' (Graz, 14-17 July 2008) to illustrate the geometric morphometry applied to ostracods and to Josef Knoblechner for teaching SL to extract TPS images from ostracod photos.

\section{Manuscript received 29 May 2007 Manuscript accepted 10 September 2009}

\section{REFERENCES}

Artheau, M. 2007. Geographical review of the ostracod genus Vestalenula (Darwinulidae) and a new subterranean species from southern France. Invertebrate Systematics, 21: 471-486.

Baltanás, A., Brauneis, W., Danielopol, D.L. \& Linhart, J. 2003. Morphometric methods for applied ostracodology: tools for outline analysis of nonmarine ostracodes. In: Park, L.E. \& Smith, A.J. (Eds), Bridging the Gap: Trends in the ostracod biological and geological sciences. The Paleontological Society Papers, 9: 101-118.

Benvenuti, M., Bertini, A., Esu, D. et al. 2004. Baccinello-Cinigiano (BC) Basin. In: Sagri, M., Martini, I.P., Pascucci, V., Cavinato, G.P. \& Sandrelli, F. (Eds), Sedimentary and tectonic evolution of selected Neogene-Quaternary basins of the Appenines (Italy). Field-trip guidebook 32 International Geological Congress, P15, 4: 16-21.

Brauneis, W., Neubauer, W., Linhart, J. \& Danielopol, D.L. 2006a. Morphomatica approximation of Ostracoda, Computer Program version 1.6.01 Limnological Institute, Austrian Academy of Sciences, Mondsee (available at: http://palstrat.uni-graz.at/morphomatica/ morphomatica_e.htm).

Brauneis, W., Linhart, J., Stracke, A., Danielopol, D.L., Neubauer, W. \& Baltanás, A. 2006b. Morphomatica (Version 1.6) User Manual/ Tutorial. Mondsee. User Manual/Tutorial. Limnological Institute, Austrian Academy of Sciences, Mondsee: 1-82 (available at: http:// palstrat.uni-graz.at/morphomatica/morphomatica_e.htm).

Cabral, M.C., Colin, J.-P. \& Carbonel, P. 2005. Espèces pléistocènes de la famille Darwinulidae Brady et Norman, 1889 (Ostracodes), en Algarve, sud Portugal. Revue de micropaléontologie, 48(2): 51-62.

Carbonnel, G., Weidmann, M. \& Berger, J.P. 1985. Les ostracodes lacustres et saumatres de la molasse de Suisse occidentale. Revue de Paleobiologie, 4(2): 215-251.

Ciampaglio, C.N., Kemp, M. \& McShea, D.W. 2001. Detecting changes in morphospace occupation pattern in the fossil record: characterisation and analysis of measure of disparity. Paleobiology, 27: 695-715.

Clarke, K.R. \& Gorley, R.N. 2001. Primer ver. 5: user manual/tutorial. PRIMER-E Ltd, Plymouth.

Clarke, K.R. \& Gorley, R.N. 2006. Primer v6. Computer program. PRIMER-E Ltd, Plymouth.

Clarke, K.R. \& Warwick, R.M. 2001. Change in Marine Communities: An approach to statistical analysis and interpretation. Plymouth Marine Laboratory, Plymouth.

Danielopol, D.L. 1970. Une nouvelle espèce du genre Darwinula des eaux souterraines de Romanie et quelques remarques sur la morphologie des Darwinulidae (Ostracoda-Podocopida). Travaux de l'Istitut de Spéleologie "Emile Racovitza", 9: 135-149.

Danielopol, D.L. 1980. An essay to assess the age of the freshwater interstitial ostracods of Europe. Bijdragen tot de Dierkunde, 50(2): 243-291.

Danielopol, D.L., Artheau, M. \& Marmonier, P. 2009. Site prioritization for the protection of rare subterranean species - the cases of two ostracods from south-western France. Freshwater Biology, 54(4): 877-884.

Davis, J. \& Christidis, F. 1997. A Guide to Wetland Invertebrates of southwestern Australia. Western Australian Museum, Perth, 177 pp.

Freels, D. 1980. Limnische Ostrakoden aus Jungtertiär und Quartär der Türkei. Geologische Jahrbuch, B39: 3-169.

Fubelli, G., Cipollari, P., Cosentino, D. et al. 2006. Ricostruzione paleoambientale ed evoluzione stratigrafico-sequenziale della fascia costiera pliocenica compresa tra le foci del Paleo-Farfa e del Paleo-
Corese (Sabina, Italia centrale). GEOSED 2006, Modena, 25-29 settembre 2006. Abstract: 57.

Ghetti, P., Anadón, P., Bertini, A., Esu, D., Gliozzi, E., Rook, L. \& Soulié-Märsche, I. 2002. The Early Messinian Velona basin (Siena, central Italy): paleoenvironmental and paleobiogeographical reconstructions. Palaeogeography, Palaeoclimatology, Palaeoecology, 187: $1-33$.

Gross, M. 2004. Zur Ostracodenfauna (Crustacea), Paläoökologie und Stratigrafie der Tongrube Mataschen (Unter-Pannonium, Steirisches Becken, Österreich). Joannea Geologie und Paläontologie, 5: 49-129.

Gross, M., Minati, K., Danielopol, D.L. \& Piller, W. 2008. Environmental changes and diversification of Cyprideis in the Late Miocene of the Styrian Basin (Lake Pannon, Austria). Senckerbergiana Lethaea, 88: $161-182$.

Harding, J.P. 1962. Mungava munda and four other new species of ostracod crustaceans from fish stomachs. In: Wolff, T. (Ed.), The Natural History of Rennel Island, British Solomon Islands. Copenhagen, Danish Science Press, 4: 51-62.

Hoschek, J. \& Lasser, D. 1993. Fundamentals of Computer Aided Geometric Design. A.K. Peters, Wellesley, MA.

Iepure, S., Namiotko, T. \& Danielopol, D.L. 2007. Evolutionary and taxonomic aspects within the species group Pseudocandona eremita (Vejdovský) (Ostracoda, Candonidae). Hydrobiologia, 585: 159-180.

Janz, H. 1997. Die Ostrakoden der kleini-Schichten des miozänen Kratersees von Steinheim am Albuch (Süddeutschand). Stuttgarter Beitrag Naturkunde, B, 251: 1-104.

Janz, H., Jellinek, T. \& Hamedani, A. 2001. Holozane SusswasserOstracoden aus dem Iran. Senckenbergiana Lethaea, 81: 183-205.

Kiss, R. 1959. Quelques Ostracodes nouveaux et intéressants de la région de l'extrémité Nord du Lac Tanganika. Revue de Zoologie et de Botanique Africaines, 59(1-2): 81-105.

Klie, W. 1935. Ostracoda aus dem tropischen Westafrica. Archiv für Hydrobiologie, 28: 35-68.

Klie, W. 1939. Ostracoden aus dem Kenia-Gebiet, vornehmlich von dessen Hochgebirgen. Internationale Revue der Gesamten Gydrobiologie und Hydrographie, 30: 99-161.

Krstić, N. 1995. Ostracodes of Lower and Middle Paludinian Beds of Fruska. In: Marinescu, Fl. \& Papaianopol, I. (Eds), Chronostratigraphie und Neostratotypen. Neogen der Zentrale Paratethys. 9. Dacien. Romanian Akademie, Bucarest: 387-425.

Krstić, N. 2006. Pliocene ostracodes of the Paludinian Beds in the Pannonian Plain, Serbian part. Herald of the Natural History Museum, Belgrade, 409 pp.

Ligios, S., Benvenuti, M., Gliozzi, E., Papini, M. \& Rook, L. 2008. Late Miocene palaeoenvironmental evolution of the Baccinello-Cinigiano Basin (Tuscany, central Italy) and new autoecological data on rare fossil fresh- to brackish-water ostracods. Palaeogeography, Palaeoclimatology, Palaeoecology, 264(3-4): 277-287.

Ligios, S., Gliozzi, E. \& Krstić, N. 2006. Occurrence of Vestalenula (Darwinuloidea, Ostracoda) in the Neogene of Italy and Serbia. Riassunti Giornate di Paleontologia 2006, Trieste 8-11 Giugno: 51.

Lutz, A.K.von. 1965. Jungtertiäre Süsswasser-Ostracoden aus Süddeutschland. Geologische Jahrbuch, 82: 271-330.

Malz, H. \& Moayedpour, E. 1973. Miozane Susswasser-Ostracoden aus der Rhon. Senckenbergiana Lethaea, 54: 281-309.

Martens, K. \& Rossetti, G. 1997. On two new species of Darwinula Brady \& Robertson 1885 (Crustacea, Ostracoda) from South African dolomitic springs. Bulletin van het Koninklijk Belgisch Instituut voor Natuurwetenschappen, Biologie, 67: 57-66.

Martens, K. \& Rossetti, G. 2002. On the Darwinulidae (Crustacea: Ostracoda) from Oceania. Invertebrate Systematics, 16: 195-208.

Martens, K., Rossetti, G. \& Fuhrmann, R. 1997. Pleistocene and Recent species of the family Darwinulidae Brady \& Norman, 1889 (Crustacea, Ostracoda) in Europe. Hydrobiologia, 357: 99-116.

Mary, N. \& Marmonier, P. 2000. First survey of interstitial fauna in New Caledonian rivers: influence of geological and geomorphological characteristics. Hydrobiologia, 418: 199-208.

Mazzini, I. \& Sardella, R. 2004. Notes on the freshwater ostracods (Arthropoda: Crustacea). Fauna of Arabia, 20: 181-191. 
Meulenkamp, J.E. 1979. Field guide to the Neogene of Crete. Publications of the Department of Geology \& Paleontology, University of Athens, A, 32.

Minati, K., Cabral, M.C., Pipík, R., Danielopol, D.L., Linhart, J. \& Neubauer, W. 2008. Morphological variability among European populations of Vestalenula cylindrica (Straub) (Crustacea, Ostracoda). Palaeogeography, Palaeoclimatology, Palaeoecology, 274: 296-305.

Mostafawi, N. 1988. Süßwasser-Ostracoden aus dem Plio-Pleistozän der Insel Kos (Griechenland). Meyniana, 40: 175-193.

Mostafawi, N. 1989. Neogene Ostracoden von Chersonisos und Vrysses (Kreta, Griechenland). Neues Jahrbuch für Geologie und Paläontologie, Abhandlungen, 179(2): 183-201.

Mostafawi, N. 1990. Neogene Ostracoden von Kythira, Griechenland. Courier Forschugsinstitut Senckenberg, 123: 161-179.

Mostfawi, N. 1994. Ostracoden aus dem Ober-Pliozän und dem Ober.Pleistozän des N-Peloponnes, Griechenland. Neues Jahrbuch Für Geologie und Paläontologie Monatsheft, 5: 309-319.

Neale, J.W. \& Victor, R. 1978. The Lund University Expedition freshwater ostracoda from Sri Lanka (Ceylon). Canadian Journal of Zoology, 56(5): 1081-1087.

Pietrzeniuk, E. 1991. Die Ostrakondenfauna des Eem-Interglazials von Schonfeld, $\mathrm{Kr}$ Calau (Niederlausitz). Natur und Landschaft in der Niederlausitz, special issue: 92-116.

Pinto, I.D. \& Kotzian, S.C.B. 1961. New ostracodes of the family Darwinulidae and the variation in their muscle scars. Universidade do Rio Grande do Sul, Instituto de Ciéncias Naturais, Boletim, 11: $5-64$.

Pinto, R.L., Rocha, C.E.F. \& Martens, K. 2003. On two new species of Vestalenula Rossetti \& Martens, 1998 (Crustacea, Ostracoda, Darwinulidae) from semiterrestrial habitats in São Paolo State (Brazil). Zoological Journal of the Linnean Society, 139: 305-313.

Pipik, R. \& Bodergat, A.M. 2003. Ostracodes du Miocène supérieur du Bassin de Turiec (Slovaquie): familles Darwinulidae et Ilyocyprididae. Revista Espagnola de Micropaleontologia, 35(3): 345-355.

Rohlf, F.J. 2002. BIOMstat: Statistical Software for Biologists Version 3.30q, 1996-2002. Applied Biostatistics, Inc., Port Jefferson, USA.
Rohlf, F.J. 2003. TPS-dig, Computer Program version 1.37. Department of Ecology and Evolution, State University of New York at Stony Brook.

Rook, L. \& Ghetti, P. 1997. Il bacino neogenico della Velona (Toscana, Italia): stratigrafia e primi ritrovamenti di vertebrati fossili. Bollettino della Società Geologica Italiana, 116: 335-346.

Rossetti, G. \& Martens, K. 1998. Taxonomic revision of the Recent and Holocene representatives of the Family Darwinulidae (Crustacea, Ostracoda), with a description of three new genera. Bulletin van het Koninklijk Belgisch Institut voor Natuurwetenschappen, Biologie, 68: $55-110$.

Rossetti, G. \& Martens, K. 1999. Contribution to taxonomy and distribution of Vestalenula Rossetti \& Martens, 1998 (Crustacea, Ostracoda, Darwinulidae), with the description of two new species. Bulletin van het Koninklijk Belgisch Institut voor Natuurwetenschappen, Biologie, 69: 57-66.

Schön, I. \& Martens, K. 2007. Is the molecular evidence for sex in Vestalenula cornelia? $6^{\circ}$ European Ostracodologist's Meeting, Frankfurt am Main September 2007, Abstract Volume: 45.

Smith, R.J., Kamiya, T. \& Horne, D.J. 2006. Living males of the 'ancient asexual' Darwinulidae (Ostracoda: Crustacea). Proceedings of the Royal Society, B, 273: 1569-1578.

Sokač, A. 1979. Miocenski ostrakodi Sinjskog polja. Geološki Vjesnik, 31: $137-144$.

Straub, E.W. 1952. Mikropaläontologische Untersuchungen im Tertiär zwischen Ehigen und Ulm a. d. Donau. Geologische Jahrbuch, 66: 433-523.

Witt, W. 1998. Die Miozäne Fossil-Lagerstätte Sandelzhausen 14. Ostracoden. Mitteilungen der Bayerischen Staatssammlung für Paläontologie und historische Geologie, 38: 135-165.

Witt, W. 2000. Süßwasserostracoden der Miozänen Vorlandmolasse Süddeutschlands. Mitteilungender Bayerischen Staatssammlung für Paläontologie und historische Geologie, 40: 109-151.

Zelditch, M.L., Swiderski, D.L., Sheets, H.D. \& Fink, W.L. 2004. Geometric morphometrics for biologists: a Primer. Elsevier Academic Press, San Diego, 427 pp. 